\title{
PERAN INOVASI PRODUK MEMEDIASI ORIENTASI PASAR TERHADAP KINERJA PEMASARAN PRODUSEN MAKANAN OLEH-OLEH KHAS BALI
}

\author{
Putu Diah Saraswati ${ }^{1}$ \\ I Wayan Santika ${ }^{2}$ \\ ${ }^{1,2}$ Fakultas Ekonomi dan Bisnis Universitas Udayana, Bali, Indonesia \\ email: diahsaraswati92@yahoo.com
}

\begin{abstract}
ABSTRAK
Meningkatnya jumlah kunjungan wisatawan ke Bali membuat adanya kecenderungan wisatawan untuk membeli oleh-oleh khas Bali, hal tersebut akan mempengaruhi penjualan dari produsen makanan oleh-oleh khas Bali yang merupakan ukuran dari kinerja pemasaran produsen tersebut. Tujuan penelitian ini adalah untuk menganalisis peran inovasi produk dalam memediasi pengaruh orientasi pasar terhadap kinerja pemasaran. Sampel yang digunakan sebanyak 100 orang. Data dikumpulkan dengan menyebarkan kuesioner secara langsung dan menggunakan skala likert. Teknik analisis data yang digunakan adalah analisis jalur (path analysis) serta uji sobel. Hasil analisis menunjukkan bahwa orientasi pasar berpengaruh positif dan signifikan terhadap inovasi produk dan kinerja pemasaran. Inovasi produk berpengaruh positif dan signifikan terhadap kinerja pemasaran. Inovasi produk berperan secara signifikan memediasi pengaruh orientasi pasar terhadap kinerja pemasaran. Kata Kunci: orientasi pasar, inovasi produk, kinerja pemasaran
\end{abstract}

\begin{abstract}
The increasing number of tourist visits to Bali makes the tendency of tourists to buy Balinese souvenirs, this will affect the sales of Balinese souvenirs which are a measure of the producers' marketing performance. The purpose of this study was to analyze the role of product innovation in mediating the effect of market orientation on marketing performance. The sample used was 100 people. Data was collected by distributing questionnaires directly and using a Likert scale. The data analysis technique used is path analysis (path analysis) and sobel test. The results of the analysis show that market orientation has a positive and significant effect on product innovation and marketing performance. Product innovation has a positive and significant effect on marketing performance. Product innovation plays a significant role in mediating the effect of market orientation on marketing performance.

Keywords: market orientation, product innovation, marketing performance
\end{abstract}




\section{PENDAHULUAN}

Pariwisata merupakan salah satu sektor pembangunan yang saat ini sedang dikembangkan oleh pemerintah. Hal ini disebabkan pariwisata memiliki peranan penting dalam pembangunan Indonesia khususnya sebagai penghasil devisa negara di samping sektor migas. Bali merupakan salah satu daerah tujuan wisata internasional yang sangat terkenal di dunia. Sektor kepariwisataan telah menjadi alat penggerak perekonomian dan pembangunan di Bali sejak tahun 1970-an. Oleh karena itu kepariwisataan merupakan bagian yang sangat erat dan tidak dapat dipisahkan lagi dalam kehidupan masyarakat dan pembangunan di Bali. Perkembangan pariwisata di Bali yang kian pesat telah membuat Pulau Bali sebagai salah satu destinasi favorit bagi wisatawan lokal maupun wisatawan mancanegara. Untuk mengukur kegiatan pariwisata di Bali dapat dilihat dari tingkat kunjungan wisatawan ke Bali. Berikut jumlah kunjungan wisatawan ke Bali pada tahun 2015 sampai 2017.

\begin{tabular}{ccccc} 
& \multicolumn{4}{c}{ Tabel 1. } \\
\multicolumn{3}{c}{ Perkembangan Kunjungan Wisatawan Ke Bali Tahun 2015-2017 } \\
\cline { 1 - 3 } No & Tahun & \multicolumn{2}{c}{ Jenis Wisatawan } & Jumlah \\
\cline { 3 - 4 } & & Domestik & Internasional & \\
\hline 1 & 2015 & 7147100 & 4001835 & 11148935 \\
2 & 2016 & 8643680 & 4927937 & 13571617 \\
3 & 2017 & 8735633 & 5697739 & 14433372 \\
\hline
\end{tabular}

Sumber : Badan Pusat Statistik Provinsi Bali,2018

Berdasarkan pada Tabel 1. dapat dilihat perkembangan peningkatan jumlah wisatawan yang berkunjung ke Bali dari tahun ke tahun. Mulai dari tahun 2015 yaitu kunjungan wisatawan sebesar 11.148.935 orang. Pada tahun 2016 mengalami peningkatan sebesar $21.73 \%$ sedangkan pada tahun 2017 mengalami peningkatan sebesar $6.35 \%$. Adanya peningkatan jumlah wisatawan yang terjadi disetiap tahunnya yaitu pada tahun 2015-2017 menjadi peluang yang dapat dimanfaatkan para pelaku bisnis untuk mengembangkan ide bisnis yang inovatif.

Berkembangnya industri pariwisata turut berpengaruh terhadap perkembangan wisata kuliner. Wisata kuliner merupakan salah satu wisata yang banyak menarik perhatian wisatawan untuk berkunjung ke suatu daerah. Adanya perbedaan kuliner di setiap daerah menjadi ciri khas tersendiri untuk daerah tersebut. Berdasarkan data dari Badan Statistik Pusat Provinsi Bali (2018) sub sektor kuliner mendominasi struktur ekonomi kreatif di Bali, dari 16 sub sektor ekonomi kreatif persentase kuliner mencapai 41.4 persen. Sub sektor kuliner hampir 2 tahun masih tetap mendominasi terhadap sub sektor lainnya. Walaupun perkembangan industri kreatif itu sifatnya dinamis, namun tidak ada perubahan yang signifikan.

Melihat perkembangan pariwisata dan turut berpengaruhnya perkembangan wisata kuliner hingga sub sektor kuliner mendominasi struktur ekonomi kreatif di Bali, banyak perusahaan membuka bisnis kuliner di bidang oleh-oleh khas Bali sebagai peluang bisnis. Usaha oleh-oleh di Bali sebagai sebuah industri kuliner dan pasar makanan yang menjanjikan, hal tersebut membuat para perusahaan atau 
produsen oleh-oleh mengembangkan berbagai macam jenis produk oleh-oleh seperti pie susu, pia, kacang-kacangan, keripik dan lain-lain. Berikut merupakan daftar produsen makanan oleh-oleh khas Bali yang terdapat di Kota Denpasar tahun 2017.

\begin{tabular}{|lcccccc}
\multicolumn{7}{c}{ Tabel 2. } \\
\multicolumn{7}{c}{ Perkembangan Produsen Makanan Oleh-oleh Khas Bali di Kota Denpas } \\
Tahun 2015-2017
\end{tabular}

Sumber: Dinas Perindustrian dan Perdagangan Kota Denpasar,2018

Berdasarkan pada Tabel 2. dapat dilihat perkembangan produsen makanan oleh-oleh khas Bali dari tahun ke tahun. Mulai dari tahun 2015 produsen makanan oleh-oleh khas Bali di Kota Denpasar sebesar 122 produsen. Pada tahun 2016 dengan produsen mengalami peningkatan sebesar 2,46\% dan pada tahun 2017 mengalami peningkatan sebesar $6,4 \%$. Jumlah produsen makanan oleh-oleh khas Bali terus mengalami peningkatan pada tahun 2015-2017. Hal ini berarti bahwa masyarakat melihat adanya peluang bisnis di bidang usaha makanan oleh-oleh khas Bali menjanjikan serta menguntungkan sehingga jumlah produsen ini pun meningkat setiap tahunnya.

Terjadinya peningkatan jumlah kunjungan wisatawan ke Bali membuat adanya kecenderungan wisatawan untuk membeli makanan oleh-oleh khas Bali sebagai kenangan berwisata ke Pulau Bali dan hendaknya harus diikuti dengan peningkatan produksi makanan oleh-oleh khas Bali setiap tahunnya, hal tersebut akan mempengaruhi penjualan dari produsen makanan oleh-oleh khas Bali yang merupakan ukuran dari kinerja pemasaran produsen tersebut. Kinerja pemasaran adalah sesuatu yang digunakan untuk mengukur keberhasilan strategi yang digunakan perusahaan dalam memasarkan produknya di pasar (Mulyani \& Mudiantono, 2015). Menurut Basuki \& Widyanti (2014), kinerja pemasaran merupakan ukuran keberhasilan dari suatu perusahaan yang diukur setiap jangka waktu yang telah ditentukan. Hasil ini dapat dikatakan sebagai nilai dari setiap aktivitas yang telah disusun dan dilaksanakan untuk dapat mengidentifikasi apakah strategi yang dibuat dan pelaksanaannya adalah tepat atau malah sebaliknya. Dalam melakukan kinerja pemasaran, tidak akan bisa berjalan tanpa memperhatikan orientasi pasar untuk mendapatkan hasil kinerja yang baik. Melakukan orientasi pasar merupakan sesuatu yang penting bagi perusahaan sejalan dengan meningkatnya persaingan global dan perubahan dalam kebutuhan pelanggan dimana perusahaan menyadari bahwa mereka harus selalu dekat dengan pasarnya (Bakti \& Harun, 2011)

Menurut Pertiwi \& Siswoyo (2016), orientasi pasar adalah kondisi dimana sebuah perusahaan yang melakukan suatu keputusan berdasarkan kondisi riil di pasar dan melakukan pendekatan-pendekatan pada pasar dengan cara penelitian dan memahami nilai-nilai yang berlaku. Perusahaan yang berorientasi pada pasar adalah perusahaan yang menjadikan pelanggan sebagai kiblat bagi perusahaan untuk 
menjalankan bisnisnya, artinya perusahaan yang selalu berusaha memahami apa yang dibutuhkan dan diinginkan para pelangganya (Utaminingsih, 2016)

Selain orientasi pasar, inovasi juga dapat dijadikan sebagai salah satu strategi dalam meningkatkan kinerja pemasaran (Guspul, 2016). Inovasi produk diperlukan untuk memenuhi permintaan pasar sehingga inovasi produk dapat dijadikan sebagai keunggulan kompetitif suatu perusahaan (Asashi \& Sukaatmadja, 2017). Menurut Haryanti \& Nursusila (2016) inovasi produk merupakan suatu proses penciptaan produk yang dimulai dari tahapan pasar yang bertumpu pada evaluasi terhadap kebutuhan pelanggan, penciptaan ide-ide, pengembangan proses atau pengenalan produk baru. Suatu perusahaan yang berorientasi pada pasar dan berinovasi terhadap suatu produk dipercaya mampu meningkatkan kinerja pemasaran (Asashi \& Sukaatmadja, 2017). Menurut Narastika \& Yasa (2012) persaingan bisnis yang begitu ketat mengharuskan perusahaan untuk lebih meningkatkan kinerja pemasaran perusahaan, karena keberhasilan suatu produk akan berpengaruh pada kinerja pemasarannya.

Penelitian yang dilakukan berdasarkan pada beberapa temuan dari penelitian sebelumnya tentang pengaruh inovasi produk, orientasi pasar terhadap kinerja pemasaran dengan hasil yang berbeda-beda. Dalam penelitian Narastika \& Yasa (2012) menyatakan bahwa inovasi produk dan keunggulan bersaing berperan memediasi hubungan antara orientasi pasar terhadap kinerja pemasaran. Hasil penelitian yang dilakukan oleh Julina \& Kusuma (2017) orientasi pasar berpengaruh positif dan signifikan terhadap kinerja pemasaran pada Fashion Rretail di Kota Denpasar. Pengaruh ini memiliki arti semakin optimal orientasi pasar yang ada, maka semakin optimal kinerja pemasaran yang berarti semakin baik prestasi pasar suatu produk jika memiliki proses pengelolaan bisnis yang baik, namun bertolak belakang dengan hasil penelitian Campo (2014); dan Im et al. (2015) serta Setyawati (2013) yang menyatakan bahwa orientasi pasar tidak berpengaruh secara positif terhadap kinerja pemasaran pada UMKM Perdagangan di Kabupaten Kebumen.

Hasil penelitian terdahulu tentang inovasi produk terhadap kinerja pemasaran, yaitu Pardi et al. (2014) menyatakan bahwa terdapat dampak positif dan signifikan dari inovasi produk terhadap kinerja pemasaran. Selaras dengan penelitian Suendro (2011), bahwa inovasi produk memiliki pengaruh yang positif dan signifikan terhadap kinerja pemasaran pada Industri Kecil dan Menengah Batik Pekalongan.

Tujuan dari penelitian ini adalah sebagai berikut, 1) Untuk menjelaskan pengaruh orientasi pasar terhadap inovasi produk pada Produsen Makanan Oleholeh Khas Bali di Kota Denpasar. 2) Untuk menjelaskan pengaruh orientasi pasar terhadap kinerja pemasaran pada Produsen Makanan Oleh-oleh Khas Bali di Kota Denpasar, 3) Untuk menjelaskan pengaruh inovasi produk terhadap kinerja pemasaran pada Produsen Makanan Oleh-oleh Khas Bali di Kota Denpasar. 4) Untuk menjelaskan peran inovasi produk dalam memediasi pengaruh orientasi pasar terhadap kinerja pemasaran pada Produsen Makanan Oleh-oleh Khas Bali di Kota Denpasar.

Manfaat dari penelitian ini adalah sebagai berikut, 1) Manfaat teoritis, penelitian ini diharapkan dapat bermanfaat bagi akademisi maupun peneliti-peneliti 
selanjutnya dalam memperkaya ilmu pengetahuan yang berkaitan dengan orientasi pasar, inovasi produkserta dampaknya terhadap kinerja pemasaran. 2) Manfaat praktis, penelitian ini diharapkan dapat bermanfaat bagi perusahaan dalam mengembangkan inovasi produk serta orientasi pasar merupakan hal yang sangat penting untuk dimiliki oleh para podusen makanan oleh-oleh khas Bali, melihat semakin meningkatnya persaingan pada lingkungan bisnis usaha oleh-oleh yang menuntut perusahaan untuk meningkatkan kinerja pemasarannya khususnya yang bergerak pada sektor produk makanan oleh-oleh khas Bali.

Kinerja pemasaran merupakan pertumbuhan penjualan yang didasarkan pada sejauh mana perusahaan mampu mempertahankan konsumen yang ada atau menambah jumlah konsumen yang baru. Dengan demikian, dalam persaingan bisnis yang semakin ketat, perusahaan yang mampu meningkatkan pertumbuhan penjualan berarti memiliki kinerja yang baik (Julina \& Kusuma, 2017). Kinerja pemasaran adalah hasil dari keseluruhan baik itu usaha, strategi, maupun kinerja yang telah dijalankan oleh suatu perusahaan (Irawan, 2015)

Orientasi pasar merupakan faktor penting yang memungkinkan perusahaan memahami pasar dan mengembangkan strategi produk dan jasa untuk memenuhi kebutuhan pelanggan dan kebutuhan pasar. Perusahaan yang melakukan orientasi pasar akan memiliki dasar perbaikan yang lebih cepat, serta akan tercermin pada kesuksesan produk perusahaan, profitabilitas, market share, dan keunggulan kompetitif yang berkelanjutan. Perusahaan yang belum berorientasi pasar adalah posisi yang baik untuk mengembangkan dan meningkatkan posisi perusahaan menjadi lebih khas (relatif terhadap persaingan) dalam jangka panjang (Kumar et al., 2011)

Orientasi pasar diukur dalam 3 dimensi yaitu orientasi pesaing, orientasi pelanggan, dan koordinasi antar fungsional (Altuntaş et al., 2013). 1) Orientasi pesaing, Orientasi pesaing adalah kemauan perusahaan untuk memonitor strategi yang diterapkan para pesaingnya(Mulyani \& Mudiantono, 2015). 2) Orientasi pelanggan, usaha perusahaan untuk memahami pelanggan dengan baik secara terus menerus untuk menciptakan nilai superior bagi perusahaan Organisasi yang berorientasi pada pelanggan selalu berusaha menjadi yang terdepan dengan menyesuaikan bauran pemasaran dengan pengetahuan tentang keinginan pasar atau pelanggan (Safarnia et al., 2011). Menurut May-Chiun et al. (2015) komponen orientasi pelanggan pada orientasi pasar dapat meningkatkan kepuasan pelanggan, meningkatkan produktifitas dan kualitas pelayanan organisasi yang mengarah pada kinerja yang lebih baik secara keseluruhan. 3) Koordinasi antar fungsional, Koordinasi antar fungsional adalah mengkoordinasikan semua fungsi organisasi dan operasi pelanggan dan informasi pasar dalam rangka menciptakan nilai bagi pelanggan (Taleghani et al., 2013)

Inovasi produk merupakan kemampuan perusahaan untuk menciptakan produk-produk yang lebih inovatif serta kreatif dibandingkan produk pesaing yang dikategorikan di dalamnya yakni produk yang baru diperkenalkan di dunia, merupakan tambahan pada lini produk baru yang telah ada maupun revisi produk yang telah ada (Vanessa \& Hendra, 2014). Atalay et al. (2013) mengukur inovasi produk menggunakan indicator, 1) Menciptakan desain yang menarik. 2) Standar kualitas. 3) Pengembangan kualitas. Back, Parboteeah, \& Nam (2018) dan Babkin, 
Lipatnikov \& Muraveva, (2015) menyatakan bahwa inovasi adalah suatu proses baru yang mampu diciptakan perusahaan untuk mengembangkan produk, menciptakan produk baru, ataupun melakukan pembaharuan pada proses produksi dan distribusi sehingga mampu bersaing untuk memperoleh segmen pasar baru.

Suliyanto \& Rahab (2012), selaras dengan penelitian yang dilakukan oleh Zhang \& Zhu (2016), menyatakan bahwa orientasi pasar berpengaruh positif terhadap inovasi produk. Altuntaş et al. (2013), menyatakan bahwa orientasi pasar berpengaruh positif terhadap inovasi pada organisasi kesehatan swasta di Turki. Penelitian Pardi et al. (2014), menunjukkan bahwa orientasi pasar memiliki pengaruh positif pada inovasi di UKM Batik Jawa Tengah. Penelitian yang dilakukan oleh Haryanto et al. (2017) orientasi pasar berpengaruh langsung dan signifikan dan positif terhadap strategi inovasi melalui penelitian yang dilakukan pada 155 manager atau pemiliki usaha meuble di Surakarta. Berdasarkan hasil kajian empiris di atas, maka dapat disusun hipotesis adalah sebagai berikut:

$\mathrm{H}_{1}$ : $\quad$ Orientasi pasar berpengaruh positif dan signifikan terhadap inovasi produk.

Julina \& Kusuma (2017), selaras dengan penelitian yang dilakukan oleh Guspul (2016), Titahena dkk. (2 012), serta Pertiwi \& Siswoyo (2016), menyatakan bahwa orientasi pasar berpengaruh positif dan signifikan terhadap kinerja pemasaran UMKM kripik buah di Kota Batu. Berdasarkan hasil kajian empiris di atas, maka dapat disusun hipotesis adalah sebagai berikut:

$\mathrm{H}_{2}$ : Orientasi pasar berpengaruh positif dan signifikan terhadap kinerja pemasaran.

Penelitian yang dilakukan oleh Pardi et al. (2014) menyatakan bahwa terdapat dampak positif dan signifikan dari inovasi produk terhadap kinerja pemasaran, selaras dengan penelitian, Killa (2015), Suendro (2011), Lapian dkk. (2016), Utaminingsih (2016), Pramesti \& Giantari (2016) Berdasarkan hasil kajian empiris di atas, maka dapat disusun hipotesis adalah sebagai berikut:

$\mathrm{H}_{3}$ : Inovasi produk berpengaruh positif dan signifikan terhadap kinerja pemasaran.

Penelitian yang dilakukan oleh Julina \& Kusuma (2017) menyatakan inovasi produk dapat memediasi secara signifikan orientasi pasar terhadap kinerja pemasaran. Asashi \& Sukaatmadja (2017), melakukan penelitian bahwa peran inovasi produk secara signifikan memediasi pengaruh orientasi pasar terhadap kinerja pemasaran. Penelitian selanjutnya oleh Pardi et al. (2014) menyatakan bahwa orientasi pasar di UKM Batik akan memberikan dampak yang signifikan terhadap kinerja pemasaran jika dimediasi oleh inovasi, serta penelitian lain yang sejalan dan bernilai positif juga dikemukakan oleh Putri (2015). Berdasarkan hasil kajian empiris di atas, maka dapat disusun hipotesis adalah sebagai berikut:

$\mathrm{H}_{4}$ : Inovasi produk mampu memediasi secara signifikan orientasi pasar terhadap kinerja pemasaran.

\section{METODE PENELITIAN}

Desain penelitian ini digolongkan pada jenis penelitian asosiatif (hubungan). Penelitian dilakukan di Kota Denpasar. Lokasi ini dipilih dengan alasan karena Kota Denpasar merupakan ibu kota Provinsi Bali sehingga menjadi pusat banyak 
aktivitas,seperti sebagai pusat perdagangan, pusat industri,dan pusat pariwisata. Kota Denpasar juga memiliki banyak objek wisata seperti Pantai Sanur, Museum Le Majiur Museum Bali, Monumen Bajra Sandhi, Monumen Puputan Badung, Taman Budaya Ardha Chandra (Art Centre Bali), serta Kota Denpasar merupakan Kota Pusaka yang diakui oleh UNESCO. Karena sebagai salah satu destinasi wisata maka disasar oleh para pebisnis sebagai lokasi atau tempat berjualan makanan oleholeh khas Bali.

Populasi dalam penelitian ini adalah produsen makanan oleh-oleh khas Bali di Kota Denpasar dengan jumlah 133 produsen makanan oleh-oleh khas Bali. Mengingat populasi penelitian dapat diketahui dengan pasti (133 produsen) maka sampel penelitian terdiri atas seluruh anggota populasi. Dengan kata lain dilakukan sensus atau dikenal dengan istilah sampel jenuh.

Terdapat dua teknik analisis yang digunakan dalam penelitian ini, yaitu statistik deskriptif dan statistik inferensial. Statistik deskriptif bertujuan untuk mengetahui karakteristik dan tanggapan responden mengenai item-item pernyataan dalam kuesioner, sedangkan statistik inferensial untuk menguji kebenaran hipotesis-hipotesis yang telah dirumuskan dengan menggunakan teknik analisis jalur (Path Analysis) disertai Uji Sobel.

\section{HASIL DAN PEMBAHASAN}

Total kuesioner yang disebar adalah 133 eksemplar, namun yang kembali dan siap diolah sebanyak 100 eksemplar dari 100 orang responden. Sebanyak 33 kuesioner tidak bisa diolah karena beberapa sebab antara lain hilang dan tidak lengkap, jawaban responden kosong, serta salah satu responden tidak bisa membaca. Adapun karakteristik dari responden disajikan pada Tabel 3

Tabel 3.

Karakteristik Responden

\begin{tabular}{|c|c|c|c|c|}
\hline & Variabel & Klasifikasi & Jumlah (Orang) & Persentase (\%) \\
\hline \multirow[t]{3}{*}{1} & Jenis Kelamin & Laki-laki & 51 & 51 \\
\hline & & Perempuan & 49 & 49 \\
\hline & Jumlah & & 100 & 100 \\
\hline \multirow[t]{5}{*}{2} & & $\geq 20$ & 16 & 16 \\
\hline & Usia & $21-30$ & 23 & 23 \\
\hline & & $31-40$ & 49 & 49 \\
\hline & & $>40$ & 12 & 12 \\
\hline & Jumlah & & 100 & 100 \\
\hline \multirow[t]{3}{*}{3} & Pendidikan Terakhir & SMA/Sederajat & 69 & 69 \\
\hline & & Sarjana & 31 & 31 \\
\hline & Jumlah & & 100 & 100 \\
\hline
\end{tabular}

Sumber: Data diolah,2018

Sebagain besar responden yang merupakan produsen makanan oleh-oleh khas Bali di Kota Denpasar didominasi oleh responden yang berjenis kelamin laki-laki yaitu sebanyak 51 orang (51\%) dan berjenis kelamin perempuani sebanyak 49 orang atau (49\%). Berdasarkan variabel usia, sebagian besar responden didominasi oleh responden yang berusia 31-40 tahun yaitu sebanyak 49 orang (49\%). Responden dengan usia 21-30 tahun sebanyak 23 orang (23\%) menjadi responden kedua terbanyak, sedangkan responden dengan klasifikasi usia $\leq 20$ tahun sebanyak 
16 orang (16\%) berada pasa posisi ketiga sebagai responden terbanyak, dan pada klasifikasi usia $>40$ tahun sebanyak 12 orang (12\%) menjadi responden dengan jumlah paling sedikit. Hal ini menunjukan bahwa mayoritas dari produsen Makanan oleh-oleh khas Bali di Kota Denpasar adalah pada rentang usia 31-40 tahun. Berdasarkan variabel tingkat pendidikan, responden dengan pendidikan terakhir SMA atau Sederajat sebanyak 69 orang $(69 \%)$ dan responden dengan tingkat pendidikan Sarjana yaitu sebanyak 31 orang $(31 \%)$ berada pada posisi kedua. Hal ini menunjukan bahwa produsen makanan oleh-oleh khas Bali di Kota Denpasar didominasi penduduk pada tingkat pendidikan SMA atau Sederajat.

Tabel 4.

Hasil Uji Validitas

\begin{tabular}{cccccc}
\hline No & Variabel & Dimensi & Indikator & $\begin{array}{c}\text { Koefisien } \\
\text { Korelasi }\end{array}$ & Keterangan \\
\hline 1 & Orientasi Pasar (X) & Orientasi & X1.1 & O,870 & Vaalid \\
& & Pesaing (X1) & X1.2 & 0,835 & Valid \\
& & X1.3 & 0,892 & Valid \\
& & Orientasi & X2.1 & 0,869 & Valid \\
& & Pelanggan & X2.2 & 0,789 & Valid \\
& & (X2) & X2.3 & 0,825 & Valid \\
& & X2.4 & 0,748 & Valid \\
& & Koordinasi & X3.1 & 0,930 & Valid \\
& & Antar & X3.2 & 0,869 & Valid \\
& & Fungsional & X3.3 & 0,911 & Valid \\
& & (X3) & & & \\
2 & & Y1.1 & 0,686 & Valid \\
& & & Y1.2 & 0,818 & Valid \\
& & & Y1.3 & 0,814 & Valid \\
& & & Y1.4 & 0,714 & Valid \\
3 & & & Y2.1 & 0,856 & Valid \\
& & & Y2.2 & 0,746 & Valid \\
& & & Y2.3 & 0,809 & Valid \\
& & & Y2.4 & 0,606 & Valid \\
\hline
\end{tabular}

Sumber: Data diolah, 2018

Tabel 4. menunjukan bahwa nilai koefisien korelasi dari masing-masing indikator memiliki nilai lebih besar dari $0,3(\mathrm{r} \geq 0,30)$, hal ini menunjukan bahwa semua instrumen penelitian yang digunakan adalah valid.

\section{Tabel 5.}

Hasil Uji Reliabilitas

\begin{tabular}{ccccc}
\hline No & $\begin{array}{c}\text { Jumlah Item } \\
\text { Pertanyaan }\end{array}$ & Variabel & $\begin{array}{c}\text { Cronbach's } \\
\text { Alpha }\end{array}$ & Keterangan \\
\hline 1 & 10 & Orientasi Pasar & 0,943 & Reliabel \\
2 & 4 & Inovasi Produk & 0,746 & Reliabel \\
3 & 4 & Kinerja Pemasaran & 0,754 & Reliabel \\
\hline
\end{tabular}

Sumber: Data diolah, 2018

Tabel 5. menunjukan bahwa seluruh variabel dalam penelitian ini telah memenuhi syarat reliabilitas. Hal ini ditunjukan dengan nilai cronbach's alpha untuk setiap variabel lebih besar dari 0,60. 
Tabel 6.

Penilaian Responden Terhadap Variabel Orientasi Pasar

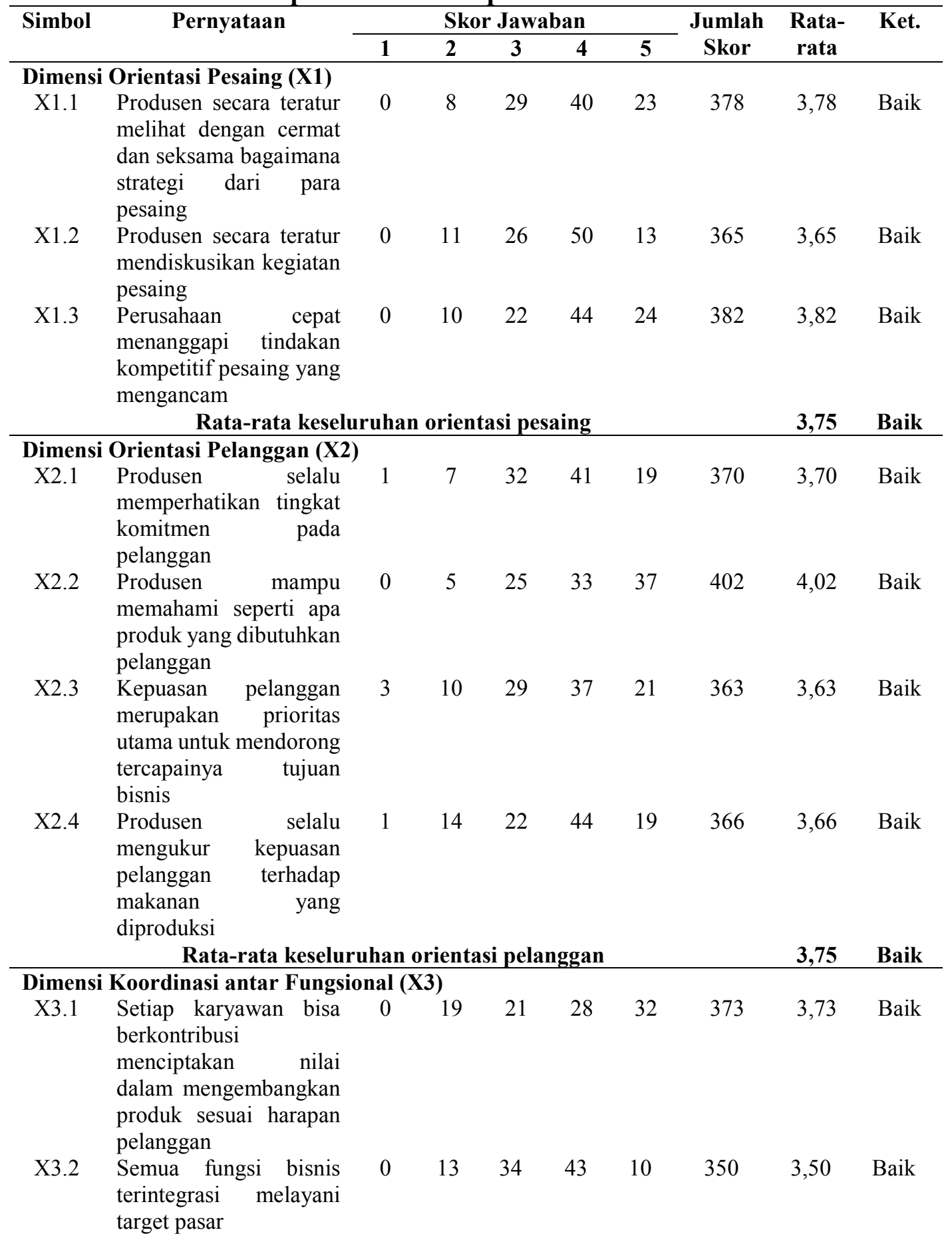


Lanjutan Tabel 6.

\begin{tabular}{|c|c|c|c|c|c|c|c|c|c|}
\hline \multirow[t]{2}{*}{ Simbol } & \multirow[t]{2}{*}{ Pernyataan } & \multicolumn{5}{|c|}{ Skor Jawaban } & \multirow{2}{*}{$\begin{array}{c}\text { Jumlah } \\
\text { Skor }\end{array}$} & \multirow{2}{*}{$\begin{array}{c}\text { Rata- } \\
\text { rata }\end{array}$} & \multirow[t]{2}{*}{ Ket. } \\
\hline & & 1 & 2 & 3 & 4 & 5 & & & \\
\hline X3.3 & $\begin{array}{lr}\text { Produsen } & \text { merespon } \\
\text { masukan } & \text { dari } \\
\text { pelanggan } & \text { agar } \\
\text { bisa } & \text { metap } \\
\text { pelanggan } & \end{array}$ & 0 & 15 & 23 & 31 & 31 & 378 & 3,78 & Baik \\
\hline & $\begin{array}{l}\text { Rata-rata keseluruh } \\
\text { Total rata-rata }\end{array}$ & lu & inas & $\begin{array}{l}\text { inta } \\
\text { enta }\end{array}$ & $\begin{array}{l}\text { ungs } \\
\text { pasa }\end{array}$ & & & $\begin{array}{l}3,67 \\
\mathbf{3 , 7 2}\end{array}$ & $\begin{array}{l}\text { Baik } \\
\text { Baik }\end{array}$ \\
\hline
\end{tabular}

Sumber: Data diolah, 2018

Berdasarkan Tabel 6. total rata-rata skor tanggapan responden terhadap variable orientasi pasar adalah sebesar 3,72 yang masuk dalam kategori baik. Skor tertinggi terdapat pada pernyataan produsen mampu memahami seperti apa produk yang dibutuhkan pelanggan, dibuktikan dengan rata-rata skor sebesar 4,02 yang dikategorikan baik. Sedangkan untuk pernyataansemua fungsi bisnis terintegrasi melayani target pasar, memperoleh rata-rata skor paling rendah sebesar 3,50. Maka dilihat dari persepsi responden, produsen mampu memahami seperti apa produk yang dibutuhkan pelanggan menjadi pernyataan yang paling berdampak untuk variable orientasi pasar dan pernyataan yang kurang berdampak adalah semua fungsi bisnis terintegrasi melayani target pasar.

Tabel 7.

Penilaian Responden Terhadap Variabel Inovasi Produk

\begin{tabular}{|c|c|c|c|c|c|c|c|c|c|}
\hline \multirow[t]{2}{*}{ Simbol } & \multirow[t]{2}{*}{ Pernyataan } & \multicolumn{5}{|c|}{ Skor Jawaban } & \multirow{2}{*}{$\begin{array}{c}\text { Jumlah } \\
\text { Skor }\end{array}$} & \multirow{2}{*}{$\begin{array}{l}\text { Rata- } \\
\text { rata }\end{array}$} & \multirow[t]{2}{*}{ Ket. } \\
\hline & & 1 & 2 & 3 & 4 & 5 & & & \\
\hline Y1.1 & $\begin{array}{l}\text { Selalu berusaha } \\
\text { menciptakan dan } \\
\text { menampilkan } \\
\text { produk dalam bentuk } \\
\text { yang berbeda dengan } \\
\text { para pesaing }\end{array}$ & 0 & 4 & 23 & 32 & 41 & 410 & 4,10 & Baik \\
\hline Y1.2 & $\begin{array}{l}\text { Harus terus } \\
\text { mengembangkan } \\
\text { produk dengan } \\
\text { desain yang menarik } \\
\text { untuk menjaga } \\
\text { keunggulan produk } \\
\text { dengan para pesaing }\end{array}$ & 0 & 5 & 14 & 29 & 52 & 428 & 4,28 & $\begin{array}{c}\text { Sangat } \\
\text { Baik }\end{array}$ \\
\hline Y1.3 & $\begin{array}{ll}\text { Penambahan } & \text { produk } \\
\text { baru } & \text { dengan } \\
\text { menetapkan } & \text { standar } \\
\text { kualitas } & \end{array}$ & 0 & 2 & 23 & 43 & 32 & 405 & 4,05 & Baik \\
\hline Y1.4 & $\begin{array}{l}\text { Selalu } \\
\text { mengembangkan } \\
\text { kualitas produk yang } \\
\text { baik }\end{array}$ & 0 & 13 & 24 & 28 & 35 & 385 & 3,85 & Baik \\
\hline & Rata-rata kese & Irul & $n$ inc & asi p & duk & & & $\mathbf{4 , 0 7}$ & Baik \\
\hline
\end{tabular}


Berdasarkan Tabel 7. total rata-rata skor tanggapan responden terhadap variable inovasi produk adalah sebesar 4,07 yang masuk dalam kategori baik. Skor tertinggi terdapat pada pernyataan, harus terus mengembangkan produk dengan desain yang menarik untuk menjaga keunggulan produk dengan para pesaing, dibuktikan dengan rata-rata skor sebesar 4,28 yang dikategorikan tinggi. Sedangkan pernyataan, selalu mengembangkan kualitas produk yang baik memperoleh ratarata skor terendah yaitu sebesar 3,85. Maka dilihat dari persepsi responden, terus mengembangkan produk dengan desain yang menarik untuk menjaga keunggulan produk dengan para pesaing menjadi pernyataan yang paling berdampak pada variable inovasi produk dan pernyataan selalu mengembangkan kualitas produk yang baik kurang berdampak pada variable inovasi produk.

\section{Tabel 8.}

Penilaian Responden Terhadap Variabel Kinerja Pemasaran

\begin{tabular}{|c|c|c|c|c|c|c|c|c|c|c|}
\hline \multirow[t]{2}{*}{ Simbol } & \multirow{2}{*}{\multicolumn{2}{|c|}{ Pernyataan }} & \multicolumn{5}{|c|}{ Skor Jawaban } & \multirow{2}{*}{$\begin{array}{c}\text { Jumlah } \\
\text { Skor }\end{array}$} & \multirow{2}{*}{$\begin{array}{c}\text { Rata- } \\
\text { rata }\end{array}$} & \multirow[t]{2}{*}{ Ket. } \\
\hline & & & 1 & 2 & 3 & 4 & 5 & & & \\
\hline Y2.1 & $\begin{array}{l}\text { Penjualan } \\
\text { mengalami } \\
\text { pertumbuhan } \\
\text { tahunnya }\end{array}$ & $\begin{array}{l}\text { selalu } \\
\text { setiap }\end{array}$ & 1 & 12 & 27 & 41 & 19 & 365 & 3,65 & Baik \\
\hline Y2.2 & $\begin{array}{l}\text { Selalu } \\
\text { menginformas } \\
\text { produk } \\
\text { memberikan } \\
\text { kepuasan } \\
\text { adanya pertur } \\
\text { pelanggan }\end{array}$ & $\begin{array}{l}\text { sikan } \\
\text { dan } \\
\text { ehingga } \\
\text { mbuhan }\end{array}$ & 0 & 9 & 22 & 42 & 27 & 387 & 3,87 & Baik \\
\hline Y2.3 & $\begin{array}{l}\text { Senantiasa } \\
\text { menambah } \\
\text { memperluas } \\
\text { pemasaran } \\
\text { produk } \\
\text { dihasilkan }\end{array}$ & $\begin{array}{r}\text { dan } \\
\text { daerah } \\
\text { untuk } \\
\text { yang }\end{array}$ & 0 & 7 & 32 & 38 & 23 & 377 & 3,77 & Baik \\
\hline Y2.4 & $\begin{array}{l}\text { Perusahaan } \\
\text { mendapatkan } \\
\text { keuntungan } \\
\text { target yang } \\
\text { ditentukan }\end{array}$ & $\begin{array}{r}\text { sesuai } \\
\text { telah }\end{array}$ & 0 & 6 & 22 & 43 & 29 & 395 & 3,95 & Baik \\
\hline & Rata-rat & ta keselv & IIIa & me & ipe & sar & & & 3,81 & Baik \\
\hline
\end{tabular}

Sumber: Data diolah, 2018

Berdasarkan pada Tabel 8. total rata-rata skor tanggapan responden terhadap variabel kinerja pemasaran sebesar 3,81 yang masuk pada kategori baik. Skor tertinggi terdapat pada pernyataan, perusahaan mendapatkan keuntungan sesuai target yang telah ditentukan yang dibutikan dengan rata-rata skor sebesar 3,95. Sedangkan pernyataan, penjualan selalu mengalami pertumbuhan setiap tahunnya mendapat rata-rata skor terendah sebesar 3,65. Maka dilihat dari persepsi responden, pernyataan Perusahaan mendapatkan keuntungan sesuai target yang telah ditentukan paling berdampak pada variabel kinerja pemasaran dan pernyataan responden penjualan selalu mengalami pertumbuhan setiap tahunnya kurang berdampak pada variabel kinerja pemasaran. 
Tabel 9.

Hasil Uji Normalitas Struktur 1

\begin{tabular}{lc}
\hline & Unstandardized Residual \\
\hline $\mathrm{N}$ & 100 \\
Kolmogorov-Smirnov $Z$ & 1,034 \\
Asymp.Sig.(2-tailed) & 0,235 \\
\hline Sumber: Data diold 2018
\end{tabular}

Sumber: Data diolah, 2018

Berdasarkan Tabel 9, dapat dilihat bahwa nilai Kolmogorov Smirnov (K-S) sebesar1,034, sedangkan nilai Asymp.Sig. (2-tailed) sebesar 0,235. Hasil tersebut mengindikasikan bahwa model persamaan regresi tersebut berdistribusi normal karena nilai Asymp.Sig. (2-tailed) lebih besar dari nilai alpha 0,05.

Tabel 10.

Uji Normalitas Struktur 2

\begin{tabular}{lc}
\hline & Unstandardized Residual \\
\hline $\mathrm{N}$ & 100 \\
Kolmogorov-Smirnov $Z$ & 0,570 \\
Asymp.Sig.(2-tailed) & 0,901 \\
\hline
\end{tabular}

Sumber: Data diolah, 2018

Berdasarkan Tabel 10, dapat dilihat bahwa nilai Kolmogorov Smirnov (K-S) sebesar 0,0570, sedangkan nilai Asymp.Sig. (2-tailed) sebesar 0,901. Hasil tersebut mengindikasikan bahwa model persamaan regresi tersebut berdistribusi normal karena nilai Asymp.Sig. (2-tailed) lebih besar dari nilai alpha 0,05.

Tabel 11.

Hasil Uji Multikolinearitas

\begin{tabular}{lcc}
\hline \multicolumn{1}{c}{ Persamaan struktur } & Variabel & Tolerance \\
\hline $\mathrm{Y}_{1}=\beta_{2} \mathrm{X}+\mathrm{e}_{1}$ & Orientasi Pasar $(\mathrm{X})$ & 1,000 \\
$\mathrm{Y}_{2}=\beta_{1} \mathrm{X}+\beta_{3} \mathrm{Y}_{1}+\mathrm{e}_{2}$ & Orientasi Pasar $(\mathrm{X})$ & 0,717 \\
& Inovasi Produk (Y1) & 0,717 \\
\hline
\end{tabular}

Sumber: Data diolah, 2018

Berdasarkan Tabel 11. dapat dilihat bahwa nilai tolerance dan VIF dari variabel orientasi pasar, dan inovasi produk menunjukkan nilai tolerance untuk setiap variabel lebih besar dari $10 \%$ dan nilai VIF lebih kecil dari 10 yang berarti model persamaan regresi bebas dari multikolinearitas.

Tabel 12.

Hasil Uji Heteroskedastisitas Struktur 1

\begin{tabular}{ccccccc}
\hline \multirow{2}{*}{ Model } & \multicolumn{2}{c}{$\begin{array}{c}\text { Unstanddardized } \\
\text { Coefficients }\end{array}$} & $\begin{array}{c}\text { Standardized } \\
\text { Coefficients }\end{array}$ & \multirow{2}{*}{ t } & \multirow{2}{*}{ Sig. } \\
\cline { 2 - 5 } & B & Std.Error & Beta & & \\
\hline 1 & (Constant) & .579 & .134 & & 4.335 & .000 \\
\hline & Orientasi Pasar & -.069 & .035 & -.193 & -1.948 & .054 \\
\hline
\end{tabular}

Sumber: Data diolah, 2018 
Pada Tabel 12. dapat dilihat bahwa nilai signifikan dari variabel orientasi pasar sebesar 0,054 . Nilai tersebut lebih besar dari 0,05 yang berarti tidak terdapat pengaruh antara variabel bebas terhadap absolute residual. Dengan demikian, model yang dibuat tidak mengandung gejala heteroskedastisitas.

Tabel 13.

Hasil Uji Heteroskedastisitas Struktur 2

\begin{tabular}{|c|c|c|c|c|c|c|}
\hline \multirow{2}{*}{\multicolumn{2}{|c|}{ Model }} & \multicolumn{2}{|c|}{$\begin{array}{c}\text { Unstanddardized } \\
\text { Coefficients }\end{array}$} & \multirow{2}{*}{$\begin{array}{c}\begin{array}{c}\text { Standardized } \\
\text { Coefficients }\end{array} \\
\text { Beta } \\
\end{array}$} & \multirow[t]{2}{*}{ t } & \multirow[t]{2}{*}{ Sig. } \\
\hline & & B & Std.Error & & & \\
\hline \multirow[t]{3}{*}{1} & (Constant) & .572 & .237 & & 2.411 & .018 \\
\hline & Orientasi Pasar & .058 & .048 & .142 & 1.203 & .232 \\
\hline & Inovasi Produk & -.107 & .068 & -.188 & -1.586 & .116 \\
\hline
\end{tabular}

Sumber: Data diolah, 2018

Pada Tabel 13. dapat dilihat bahwa nilai signifikan dari 7004ariable orientasi pasar, dan inovasi produk, masing-masing sebesar 0232 dan 0, 116. Nilai tersebut lebih besar dari 0,05 yang berarti tidak terdapat pengaruh antara 7004ariable bebas terhadap absolute residual. Dengan demikian, model yang dibuat tidak mengandung gejala heteroskedastisitas.

Tabel 14.

Hasil Analisis Jalur Persamaan Regresi 1

\begin{tabular}{|c|c|c|c|c|c|c|}
\hline & \multirow[t]{2}{*}{ Model } & \multicolumn{2}{|c|}{$\begin{array}{c}\text { Unstanddardized } \\
\text { Coefficients }\end{array}$} & \multirow{2}{*}{$\begin{array}{c}\begin{array}{c}\text { Standardized } \\
\text { Coefficients }\end{array} \\
\text { Beta } \\
\end{array}$} & \multirow[t]{2}{*}{$\mathbf{t}$} & \multirow[t]{2}{*}{ Sig. } \\
\hline & & $\mathbf{B}$ & Std.Error & & & \\
\hline \multirow[t]{5}{*}{1} & (Constant) & 2.663 & .238 & & 11.586 & .000 \\
\hline & Orientasi Pasar & .378 & .061 & .532 & 6.220 & .000 \\
\hline & R1 Square & & & & & 0.283 \\
\hline & F Statistik & & & & & 38.688 \\
\hline & Signifikansi & & & & & 0.000 \\
\hline
\end{tabular}

Berdasarkan hasil analisis jalur substruktur 1 pada Tabel 14, maka persamaan strukturalnya adalah $\mathrm{Y}_{1}=0,378 \mathrm{X}+\mathrm{e}_{1}$

Nilai koefisien regresi variabel orientasi pasar bernilai positif dengan nilai signifikansi uji t kurang dari 0,05 . Hal ini menunjukkan bahwa variabel orientasi pasar memiliki pengaruh positif yang signifikan terhadap variabel inovasi produk. Besarnya pengaruh variabel bebas terhadap variabel terikat yang ditunjukkan oleh nilai determinasi total (R Square) sebesar 0,283 mempunyai arti bahwa sebesar $28,3 \%$ variasi inovasi produkdipengaruhi oleh variasi orientasi pasar, sedangkan sisanya sebesar $71,7 \%$ dijelaskan oleh faktor lain yang tidak dimasukkan ke dalam model.

Berdasarkan hasil analisis jalur substruktur 2 pada Tabel 15. ,maka persamaan strukturalnya adalah $\mathrm{Y}_{2}=0,224 \mathrm{X}+0,629 \mathrm{Y}_{1}+\mathrm{e}_{2}$ 
Berdasarkan model substruktur 1 dan substruktur 2, maka dapat disusun model diagram jalur akhir. Sebelum menyusun model diagram jalur akhir, terlebih dahulu dihitung nilai standar error sebagai berikut :

$$
\begin{gathered}
\mathrm{Pe}_{\mathrm{i}}=\sqrt{1-\mathrm{R}_{\mathrm{i}}^{2}} \ldots \ldots \ldots \ldots \ldots \ldots \ldots \ldots \ldots \\
\mathrm{Pe}_{1}=\sqrt{1-R_{1}^{2}}=\sqrt{1-0,283}=0,846 \\
\mathrm{Pe}_{2}=\sqrt{1-R_{2}^{2}}=\sqrt{1-0,446}=0,744
\end{gathered}
$$

Tabel 15.

Hasil Analisis Jalur Persamaan Regresi 2

\begin{tabular}{cccccc}
\hline Model & \multicolumn{2}{c}{$\begin{array}{c}\text { Unstandardized } \\
\text { Coefficients }\end{array}$} & $\begin{array}{c}\text { Standardized } \\
\text { Coefficients }\end{array}$ & T & Sig. \\
\cline { 2 - 4 } & B & Std.Error & Beta & & \\
\hline 1 (Constant) & .417 & .393 & & 1.061 & .291 \\
Orientasi Pasar & .224 & .080 & .251 & 2.808 & .006 \\
Inovasi Produk & .629 & .112 & .500 & 5.606 & .000 \\
R1 Square & & & & & 0,446 \\
F Statistik & & & & & 39,093 \\
Signifikansi & & & & & 0,000 \\
\hline
\end{tabular}

Sumber : Data diolah, 2018

Berdasarkan perhitungan pengaruh error (Pei), didapatkan hasil pengaruh error $\left(\mathrm{Pe}_{1}\right)$ sebesar 0,846 dan pengaruh error $\left(\mathrm{Pe}_{2}\right)$ sebesar 0,744 . Hasil koefisien determinasi total adalah sebagai berikut :

$$
\begin{aligned}
\mathrm{R}^{2} \mathrm{~m} & =1-\left(\mathrm{Pe}_{1}\right)^{2}\left(\mathrm{Pe}_{2}\right)^{2} \ldots \ldots \ldots \\
& =1-(0,846)^{2}(0,744)^{2} \\
& =1-(0,720)(0,550) \\
& =1-0,396=0,604
\end{aligned}
$$

Hasil koefisien jalur pada hipotesis penelitian dapat dilihat pada Gambar 1:

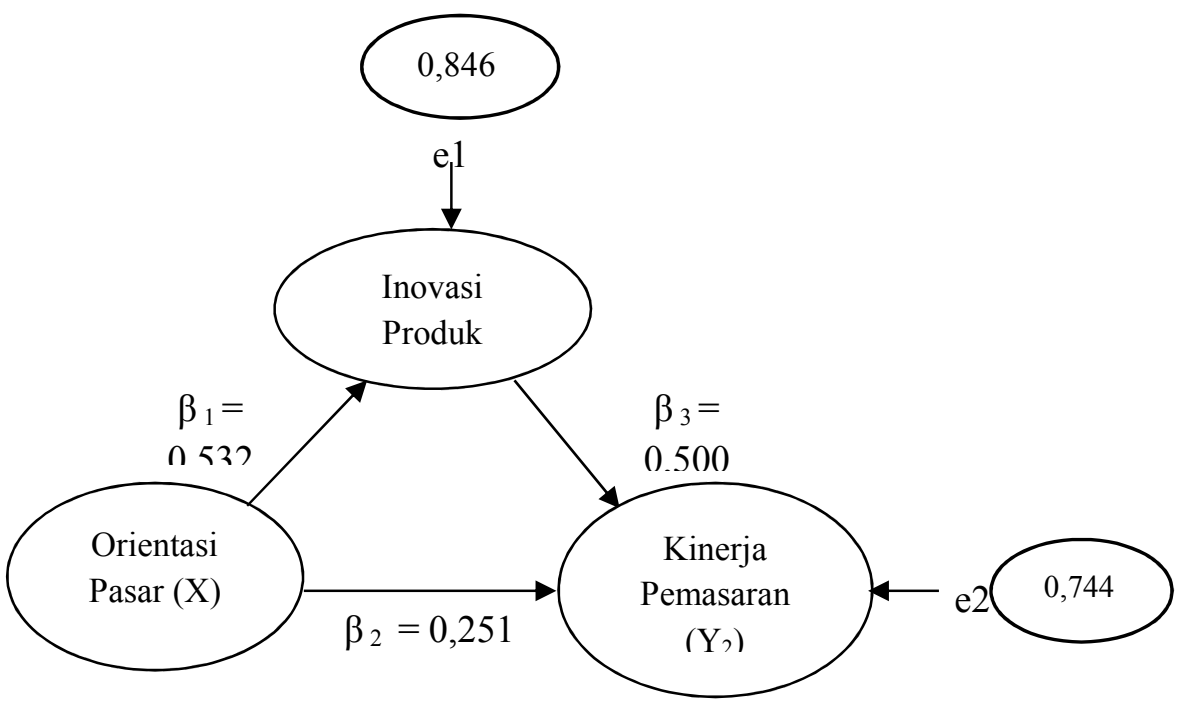

Gambar 1. Validasi Model Diagram Jalur Akhir 
Tabel 16.

Pengaruh Langsung dan Pengaruh Tidak Langsung serta Pengaruh Total Orientasi Pasar (X), Inovasi Produk (Y1), dan Kinerja Pemasaran( $\left.\mathbf{Y}_{2}\right)$

\begin{tabular}{cccc}
\hline $\begin{array}{c}\text { Pengaruh } \\
\text { Variabel }\end{array}$ & $\begin{array}{c}\text { Pengaruh } \\
\text { Langsung }\end{array}$ & $\begin{array}{c}\text { Pengaruh Tidak Langsung Melalui } \\
\text { Inovasi Produk } \\
\left(\mathbf{Y}_{\mathbf{1}}\right)\left(\boldsymbol{\beta}_{\mathbf{1}} \mathbf{x} \boldsymbol{\beta}_{\mathbf{3}}\right)\end{array}$ & Pengaruh Total \\
\hline $\mathrm{X} \rightarrow \mathrm{Y}_{1}$ & 0,532 & - & 0,532 \\
$\mathrm{X} \rightarrow \mathrm{Y}_{2}$ & 0,251 & 0,266 & 0,517 \\
$\mathrm{Y}_{1} \rightarrow \mathrm{Y}_{2}$ & 0,500 & - & 0,500 \\
\hline \multicolumn{2}{l}{ Sumber $:$ Data diolah, 2018} &
\end{tabular}

Hasil pada Tabel 16. menunjukan bahwa pengaruh langsung variabel orientasi pasar terhadap kinerja pemasaran memiliki nilai koefisien beta sebesar 0,251 namun pengaruh tidak langsung yang dimediasi oleh inovasi produk menunjukan nilai koefisien beta sebesar 0,266. Ini membuktikan bahwa inovasi produk memediasi orientasi pasar terhadap kinerja pemasaran dengan pengaruh total yang diperoleh adalah sebesar 0,517 .

Tabel 17.

Hasil Uji Sobel

\begin{tabular}{ccc}
\hline Sobel & Nilai & Keterangan \\
\hline$Z$ & 3,9534 & Memediasi \\
Sig. & 0,0001 & Signifikansi \\
\hline
\end{tabular}

Sumber : Data Diolah, 2018

Hasil dari pengujian variabel mediasi pada Tabel 17. yaitu inovasi produk didapatkan $Z$ hitung sebesar 3,9534>1,96 dengan tingkat signifikan sebesar 0,0001 $<0.05$ yang berarti $\mathrm{H} 0$ ditolak dan $\mathrm{H}_{1}$ diterima yang berarti variabel inovasi produk dinilai secara signifikan memediasi variabel orientasi pasarpada kinerja pemasaran produsen makanan oleh-oleh khas Bali di Kota Denpasar.

Berdasarkan hasil perhitungan hipotesis pertama pengaruh orientasi pasar terhadap inovasi produk dalam penelitian ini diperoleh nilai koefisien beta sebesar 0,532 dengan tingkat signifikasi $0,000<0,05$, sehingga $\mathrm{H}_{0}$ ditolak dan $\mathrm{H}_{1}$ diterima, yang mengindikasi bahwa orientasi pasar berpengaruh positif dan signifikan terhadap inovasi produk pada produsen makanan oleh-oleh khas Bali di Kota Denpasar. Hal ini dapat diartikan semakin baik produsen makanan oleh-oleh khas Bali di Kota Denpasar melakukan orientasi yang ditunjukkan dengan berorientasi padapesaing, berorientasi padapelanggan dan berkoordinasi antar fugsional maka inovasi produk akan meningkat, begitu pula sebaliknya.

Hasil penelitian ini sejalan dengan penelitian sebelumnya yang dilakukan oleh Suliyanto \& Rahab (2012), Altuntaş et al. (2013), Pardi et al. (2014), Haryanto et al. (2017) yang menyatakan bahwa orientasi pasar berpengaruh positif dan signifikan terhadap inovasi produk.

Berdasarkan hasil perhitungan hipotesis kedua pengaruh orientasi pasar terhadap kinerja pemasaran dalam penelitian ini diperoleh nilai koefisien beta sebesar 0,251 dengan tingkat signifikasi $0,000<0,05$, sehingga $\mathrm{H}_{0}$ ditolak dan $\mathrm{H}_{2}$ diterima, yang mengindikasi bahwa orientasi pasar berpengaruh positif dan 
signifikan terhadap kinerja pemasaran pada produsen makanan oleh-oleh khas Bali di Kota Denpasar. Hal ini dapat diartikan semakin baik produsen makanan oleholeh khas Bali di Kota Denpasar melakukan orientasi yang ditunjukkan denganborientasi pada pesaing, berorientasi pada pelanggan dan berkoordinasi antar fugsional maka kinerja pemasaran akan meningkat, begitu pula sebaliknya.

Hasil penelitian ini sejalan dengan penelitian sebelumnya yang dilakukan oleh Julina \& Kusuma (2017), Guspul (2016), Titahena dkk. (2012), Pertiwi \& Siswoyo (2016), Setyawati (2013) yang menyatakan bahwa orientasi pasar berpengaruh positif dan signifikan terhadap kinerja pemasaran.

Berdasarkan hasil perhitungan hipotesis ketiga pengaruh inovasi produk terhadap kinerja pemasaran dalam penelitian ini diperoleh nilai koefisien beta sebesar 0,500 dengan tingkat signifikasi $0,000<0,05$, sehingga $\mathrm{H}_{0}$ ditolak dan $\mathrm{H}_{1}$ diterima, yang mengindikasi bahwa inovasi produk berpengaruh positif dan signifikan terhadap kinerja pemasaran pada produsen makanan oleh-oleh khas Bali di Kota Denpasar. Hal ini dapat diartikan semakin baik produsen makanan oleholeh khas Bali di Kota Denpasar melakukan inovasi produk yang ditunjukkan oleh menciptakan dan mengembangkan ide-ide baru, menciptakan desain yang menarik, penambahan produk baru dan pengembangan kualitas produk maka kinerja pemasaran akan meningkat, begitu pula sebaliknya saat produsen makanan oleholeh khas Bali di Kota Denpasar tidak dapat melakukan inovasi produk dengan baik maka kinerja pemasaran akan menurun.

Hasil penelitian ini sejalan dengan penelitian sebelumnya yang dilakukan oleh Pardi et al. (2014), Suendro (2011), Lapian dkk. (2016), Utaminingsih (2016), Pramesti \& Giantari (2016) yang menyatakan bahwa inovasi produk berpengaruh positif dan signifikan terhadap kinerja pemasaran.

Berdasarkan hasil perhitungan hipotesis keempat peran inovasi produk dalam memediasi pengaruh orientasi pasar terhadap kinerja pemasaran pada produsen makanan oleh-oleh khas Bali di Kota Denpasar telah diuji dalam penelitian ini. Hasil uji pengaruh orientasi pasar terhadap kinerja pemasaran 0,251, kemudian pengaruh tidak langsungnya dengan adanya inovasi produk di dalamnya menjadi 0,266 dengan pengaruh totalnya dari semua variabel menjadi sebesar 0,517 . Hasil tersebut menunjukkan bahwa inovasi produk memediasi pengaruh orientasi pasar terhadap kinerja pemasaran. Uji sobel yang telah dihitung memperkuat hasil tersebut dengan nilai koefisien $\mathrm{z}$ yang diperoleh adalah 3,9534>1,96 dengan signifikansi $0,001<0,05$ sehingga $\mathrm{H}_{0}$ ditolak dan $\mathrm{H}_{1}$ diterima, yang mengindikasikan bahwa inovasi produk dinilai mampu memediasi pengaruh orientasi pasar terhadap kinerja pemasaran pada produsen makanan oleh-oleh khas Bali di Kota Denpasar. Semakin baik inovasi produk maka pengaruh orientasi pasar terhadap peningkatan kinerja pemasaran semakin besar, begitu pula sebaliknya.

Hasil penelitian ini sejalan dengan penelitian sebelumnya yang dilakukan oleh Julina \& Kusuma (2017), Asashi \& Sukaatmadja (2017), Pardi et al. (2014), Putri (2015) yang menyatakan bahwa inovasi produk mampu memediasi pengaruh orientasi pasar terhadap kinerja pemasaran.

Hasil penelitian ini memiliki implikasi menunjukkan pengaruh positif dan signifikan dari orientasi pasar terhadap inovasi produk dan kinerja pemasaran serta inovasi produk yang berpengaruh positif dan signifikan terhadap kinerja 
pemasaran. Penelitian ini juga menunjukkan inovasi produk mampu memediasi secara signifikan orientasi pasar dan kinerja pemasaran produsen makanan oleholeh khas Bali di Kota Denpasar.

\section{SIMPULAN}

Berdasarkan pembahasan hasil penelitian yang telah dilakukan, maka dapat disimpulkan bahwa orientasi pasar berpengaruh positif dan signifikan terhadap inovasi produk. Berarti semakin baik produsen makanan oleh-oleh khas Bali di Kota Denpasar melakukan orientasi dengan selalu memantau strategi yang diterapkan oleh pesaing, memahami pelanggan dengan baik dan mengkoordinasikan semua fungsi organisasi maka inovasi produk akan meningkat. Orientasi pasar berpengaruh positif dan signifikan terhadap kinerja pemasaran. Berarti semakin baik produsen makanan oleh-oleh khas Bali di Kota Denpasar melakukan orientasidengan selalu memantau strategi yang diterapkan oleh pesaing, memahami pelanggan dengan baik dan mengkoordinasikan semua fungsi organisasimaka kinerja pemasaran akan meningkat.

Inovasi produk berpengaruh positif dan signifikan terhadap kinerja pemasaran. Berarti semakin baik produsen makanan oleh-oleh khas Bali di Kota Denpasar melakukan inovasi produk dengan menciptakan dan mengembangkan ide-ide baru, menciptakan desain yang menarik, penambahan produk baru dan pengembangan kualitas produk maka kinerja pemasaran akan meningkat. Inovasi produk berperan dalam memediasi secara penuh pengaruh orientasi pasar terhadap kinerja pemasaran. Berarti semakin baik produsen makanan oleh-oleh khas Bali di Kota Denpasar melakukan inovasi produk menciptakan dan mengembangkan ideide baru, menciptakan desain yang menarik, penambahan produk baru dan pengembangan kualitas produk maka pengaruh orientasi pasar terhadap kinerja pemasaran semakin besar.

Produsen makanan oleh-oleh khas Bali di Kota Denpasar disarankan meningkatkan aspek penambahan varian produk yang termasuk dalam indikator inovasi produk, sehingga pengaruh orientasi pasar terhadap kinerja pemasaran dapat lebih ditingkatkan. Pada instansi terkait disarankan untuk bisa mengeluarkan peraturan tentang hak paten produk agar tidak terjadi praktek plagiat diantara produsen untuk menghindari persaingan yang tidak sehat terhadap setiap produk yang dipasarkan.

Pemerintah perlu membuat sentra oleh-oleh khas Bali bagi penjual makanan oleh-oleh khas Bali dengan menampung produk-produk UKM, karena yang ada selama ini dominan adalah milik perorangan.

\section{REFERENSI}

Altuntaş, G., Semerciöz, F., \& Eregez, H. (2013). Linking Strategic and Market Orientations to Organizational Performance: The Role of Innovation in Private Healthcare Organizations. Procedia - Social and Behavioral Sciences, 99(9), 413-419. https://doi.org/10.1016/j.sbspro.2013.10.509

Asashi, T., \& Sukaatmadja, I. P. G. (2017). Peran Inovasi Produk Memediasi Orientasi Pasar Terhadap Kinerja Pemasaran. E-Jurnal Manajemen Unud, 
$6(8), 4361-4390$.

Atalay, M., Anafarta, N., \& Sarvan, F. (2013). The Relationship between Innovation and Firm Performance: An Empirical Evidence from Turkish Automotive Supplier Industry. Procedia - Social and Behavioral Sciences, 7(5), 226-235. https://doi.org/10.1016/j.sbspro.2013.04.026

Babkin, A. V., Lipatnikov, V. S., \& Muraveva, S. V. (2015). Assessing the Impact of Innovation Strategies and R\&D Costs on the Performance of IT Companies. Procedia - Social and Behavioral Sciences, 2(7), 749-758. https://doi.org/10.1016/j.sbspro.2015.10.153

Back, Y., Parboteeah, K. P., \& Nam, D. (2018). Innovation in Emerging Markets: The Role of Consulting Firms. Academy of Management Proceedings, 2(1), 159-172. https://doi.org/10.5465/ambpp.2012.15972abstract

Badan Pusat Statistik Provinsi Bali. (2018). Jumlah Wisatawan ke Bali dari Tahun 1969-2017. Retrieved February 9, 2018, from https://bali.bps.go.id/statictable/2018/02/09/28/jumlah-wisatawan-asing-kebali-dan-indonesia-1969-2017.html

Bakti, S., \& Harun, H. (2011). Pengaruh Orientasi Pasar dan Nilai Pelanggan TerhadapKinerja Pemasaran Maskapai Penerbangan Lion Air. Jurnal Manajemen Pemasaran Modern, 3(1), 1-15.

Basuki, \& Widyanti, R. (2014). Pengaruh Strategi Keunggulan Bersaing dan Orientasi Pasar Terhadap Kinerja Pemasaran Perusahaan. Jurnal Ekonomi Dan Bisnis UNIKSA Banjarmasin, 1(2), 1-14.

Campo, S., Díaz, A., \& Yagüe, M. (2014). Hotel Innovation And Performance In Times Of Crisis. International Journal of Contemporary Hospitality Management, 26(8), 1292-1311.

Dinas Perindustrian dan Perdagangan Kota Denpasar. (2018). Jumlah Produsen Makanan Oleh-oleh Khas Bali di Kota Denpasar.

Guspul, A. (2016). Pengaruh Orientasi Pasar, Inovasi, dan Orientasi Kewirausahaan Terhadap Kinerja Pemasaran Umkm "Batako" di Kepil Wonosobo. Jurnal PPKM III, 2(2), 193-206.

Haryanti, S. S., \& Nursusila, L. (2016). Membangun Kinerja Pemasaran Berbasis Inovasi Produk dan Keunggulan Bersaing (Studi Empiris Pada Kerajinan Gitar di Kabupaten Sukoharjo). Aktual, 2(1), 1-19.

Haryanto, A. T., Haryono, T., \& Sawitri, H. S. R. (2017). Market Orientation, Learning Orientation and Small Medium Enterprises Performance:The 
Mediating Role of Innovation. International Review of Management and Marketing, 7(1), 484-491. Retrieved from http://dergipark.gov.tr/download/article-file/367109

Irawan, B. R. (2015). Dampak Inovasi Produk Terhadap Kinerja Pemasaran ( Studi Kasus Pada Peluncuran Produk Baru Dalam Industri Rokok ). Agora, 3(1), 110. Retrieved from http://publication.petra.ac.id/index.php/manajemenbisnis/article/view/2750/2462

Julina, M. M., \& Kusuma, A. A. G. A. A. (2017). Peran Inovasi Produk Memediasi Orientasi Pasar Terhadap Kinerja Pemasaran pada Fashion Retail di Kota Denpasar. E-Jurnal Manajemen Unud, 6(9), 5005-5031.

Killa, M. F. (2015). Effect of Entrepreneurial Innovativeness Orientation, Product Innovation, and Value Co-Creation on Marketing Performance. Journal of Research in Marketing, 2(3), 198. https://doi.org/10.17722/jorm.v2i3.73

Kumar, V., Jones, E., Venkatesan, R., \& Leone, R. P. (2011). Is Market Orientation a Source of Sustainable Competitive Advantage or Simply the Cost of Competing? Distinguished Chair in Marketing and Executive Director of the Center for Excellence in Brand \& Customer. Journal of Marketing, 75(January), 16-30. Retrieved from http://blogs.darden.virginia.edu/venkatesanr/files/2012/07/JM-marketorientation-2011.pdf

Lapian, A. A., James, M., \& Imelda, O. (2016). Pengaruh Orientasi Pasar dan Inovasi Produk Terhadap Kinerja Pemasaran pada PT. Prisma Dana Amurang. Jurnal EMBA, 6(2), 1330-1339. https://doi.org/10.15408/ess.v6i2.3775

May-Chiun, L., Mohamad, A. A., Ramayah, T., \& Chai, W. Y. (2015). Examining the effects of leadership, market orientation and leader member exchange (LMX) on organisational performance. Engineering Economics, 26(4), 409421. https://doi.org/10.5755/j01.ee.26.4.7656

Mulyani, I. T., \& Mudiantono. (2015). Orientasi Pasar dan Orientasi Kewirausahaan dengan Inovasi sebagai Variabel Intervening ( Studi Empiris pada Usaha Mikro Kecil dan Menengah Kota Semarang ). Journal of Management, 4(3), 1-12.

Narastika, A. . R., \& Yasa, N. N. K. (2012). Peran Inovasi Produk Dan Keunggulan Bersaing Memediasi Pengaruh Orientasi Pasar Terhadap Kinerja Pemasaran. E-Jurnal Manajemen Unud, 7(1), 1-12.

Pardi, S., Suyadi, I., \& Arifin, Z. (2014). The Effect of Market Orientation and Entrepreneurial Orientation Toward Learning Orientation, Innovation, 
Competitive Advantages and Marketing Performance. European Journal of Business and Management, 6(21), 69-80.

Pertiwi, Y. D., \& Siswoyo, B. B. (2016). Pengaruh Orientasi Pasar Terhadap Kinerja Pemasaran pada UMKM Kripik Buah di Kota Batu. Syariah Paper Accounting FEB UMS, 3(1), 231-238.

Pramesti, N. M. V., \& Giantari, I. G. A. K. (2016). Peran Orientasi Pasar Memediasi Pengaruh Orientasi Kewirausahaan terhadap Kinerja UKM Industri Kerajinan Endek. E-Jurnal Manajemen Unud, 5(9), 5754-5782.

Putri, P. I. P. P. (2015). Peran Inovasi memediasi Orientasi Pasar Terhadap Kinerja Perusahaan (Studi pada Perusahaan Konveksi di Kota Denpasar). E-Journal Manajemen Unud, 8(2), 1234-1245.

Safarnia, H., Akbari, Z., \& Abbasi, A. (2011). Review of market orientation and competitive advantage in the industrial estates companies (Kerman, Iran): Appraisal of model by AMOS graphics. World J. Soc. Science, 1(5), 132150 .

Setyawati, H. A. (2013). Pengaruh Orientasi Kewirausahaan dan Orientasi Pasar terhadap Kinerja Perusahaan melalui Keunggulan Bersaing dan Persepsi Ketidakpastian Lingkungan sebagai Prediksi Variabel Moderasi (Survey pada UMKM Perdagangan di Kabupaten Kebumen). Jurnal Fokus Bisnis, 12(02), 20-32. https://doi.org/10.1017/CBO9781107415324.004

Suendro, G. (2011). Analisis Pengaruh Inovasi Produk Melalui Kinerja Pemasaran Untuk Mencapai Keunggulan Bersaing Berkelanjutan (Studi Kasus pada Industri Kecil dan Menengah Batik Pekalongan). Jurnal Sains Pemasaran Indonesia, 10(3), 317-326.

Suliyanto, \& Rahab. (2012). The Role of Market Orientation and Learning Orientation in Improving Innovativeness and Performance of Small and Medium Enterprises. Asian Social Science, 8(1), 134-145. https://doi.org/10.5539/ass.v8n1p134

Taleghani, M., Gilaninia, S., \& Talab, S. M. (2013). Relationship between Market Orientation Culture and Business Performance. Journal of Contemporary Research Business, 5(1), 949-954.

Titahena, D. A., Syukur, A., \& Utomo, S. D. (2012). Analisis Pengaruh Orientasi Pasar, Inovasi, dan Orientasi Kewirausahaan Terhadap Kinerja Pemasaran dengan Intervening Keunggulan Bersaing (Studi Kasus Industri Menengah dan Besar Mebel dan Furniture di Kota Semarang). Jurnal Manajemen Universitas Dian Nuswantoro, 1(2), 21-30. 
Utaminingsih, A. (2016). Pengaruh Orientasi Pasar, Inovasi, Dan Kreativitas Strategi Pemasaran Terhadap Kinerja Pemasaran Pada Ukm Kerajinan Rotan Di Desa Teluk Wetan, Welahan, Jepara. Media Ekonomi Dan Manajemen, 31(2), 77-87. Retrieved from https://media.neliti.com/media/publications/149462-ID-pengaruh-orientasipasar-inovasi-dan-kre.pdf

Vanessa, D. C., \& Hendra, N. T. (2014). Pengaruh Orientasi Kewirausahaan, Inovasi Produk, dan Keunggulan Bersaing terhadap Kinerja Pemasaran Usaha Nasi Kuning. Jurnal EMBA, 2(3), 1214-1224. Retrieved from https://ejournal.unsrat.ac.id/index.php/emba/article/view/5800

Zhang, J., \& Zhu, M. (2016). Market orientation, product innovation and export performance: evidence from Chinese manufacturers. Journal of Strategic Marketing, 24(5), 377-397. https://doi.org/10.1080/0965254X.2015.1052538 